\author{
Monika Słowińska ${ }^{1}$, Aldona Maciąg ${ }^{1}$, Monika Dudzisz-Śledź ${ }^{2}$, Izabela Lasińska ${ }^{3}$, \\ Tomasz Świtaj $^{2}$, Hanna Koseła-Paterczyk ${ }^{2}$, Aleksandra Bolewska ${ }^{1}$, Katarzyna Wróbel ${ }^{1}$, \\ Paweł Golusiński $^{4,}$ 5, 6, Jacek Mackiewicz ${ }^{3,7,8}$, Piotr Rutkowski ${ }^{2}$, Witold Owczarek ${ }^{1}$ \\ ${ }^{1}$ Dermatology Clinic, Military Institute of Medicine, Central Clinical Hospital of the Ministry of National Defence in Warsaw, Poland \\ ${ }^{2}$ Department of Melanoma and Soft Tissue and Bone Sarcomas, Maria Sklodowska-Curie Institute - Oncology Center in Warsaw, Poland \\ ${ }^{3}$ Department of Clinical and Experimental Oncology, Heliodor Swiecicki Clinical Hospital, Medical University in Poznan, Poland \\ ${ }^{4}$ Department of Head and Neck Cancer Biology, Faculty of Biology and Environmental Protection, Medical University in Poznan, Poland \\ ${ }^{5}$ Department of Otolaryngology and Maxillofacial Surgery, University of Zielona Gora, Poland \\ ${ }^{6}$ Head and Neck Surgery Ward and Laryngological Oncology Clinic, Greater Poland Cancer Center, Poznan, Poland \\ ${ }^{7}$ Faculty of Biology and Environmental Protection, Medical University in Poznan, Poland \\ ${ }^{8}$ Cancer Diagnosis and Immunology Unit, Greater Poland Cancer Center, Poznan, Poland
}

\title{
Vismodegib in the treatment of basal cell carcinoma - Polish clinical experience in the frame of therapeutic program
}

\author{
Address for correspondence: \\ Dr n. med. Monika Słowińska \\ Klinika Dermatologiczna \\ Wojskowy Instytut Medyczny \\ Centralny Szpital Kliniczny Ministerstwa \\ Obrony Narodowej w Warszawie \\ e-mail: monika.slowinska@yahoo.com
}

Oncology in Clinical Practice 2019, Vol. 15, No. 3, 139-149 DOI: 10.5603/OCP.2018.0041

Translation: dr n. med. Dariusz Stencel Copyright (C) 2019 Via Medica ISSN 2450-1654

\begin{abstract}
Introduction. Vismodegib is a small-molecule inhibitor of the sonic hedgehog pathway, registered for the treatment of patients with metastatic or locally advanced basal cell carcinoma, who were disqualified from surgical excision or radiotherapy. The full treatment refund from the National Health Fund has been available in Poland since $1^{\text {st }}$ January 2018. The aim of the study was to analyse the frequency of occurrence of adverse events based on CTCAE and the treatment results based on the RECIST 1.1 criteria, in a group of patients treated for six or 12 months with vismodegib.

Material and methods. The patient database was gathered from three sites and consisted of 42 patients, who represented $53.8 \%$ of the patients treated with vismodegib in Poland. The duration of the treatment ranged between three weeks and 68 months. The median of the treatment period was 8.25 months (0.75-68); the median of the observation of patients treated for less than 12 months was eight months (6-11), and for those treated for more than 12 months it was 14 months (12-68).

Results. The summary of the treatment results after six and 12 months was performed on 29/42 and 17/42 patients accordingly. Complete response was achieved in 3/29 (10.3\%) and 3/16 (17.6\%) patients after six and 12 months of treatment, respectively, partial response in 13/29 (44.8\%) and 5/16 (29.4\%) patients, respectively, and stable disease in 13/29 (44.8\%) and 8/16 (50.0\%) patients, respectively. Progression of the disease was experienced by $7 / 42(16.6 \%)$ patients within the period of 3-28 months of treatment. One patient with brain metastases died due to the progression of the disease. Adverse events were reported in 31/42 (73.8\%) patients, more than one adverse event in a single patient was reported in 22/42 (52.3\%) patients. No serious adverse events were observed. Key words: vismodegib, basal cell carcinoma, treatment response rate, adverse events
\end{abstract}

Oncol Clin Pract 2019; 15, 3: 139-149

\section{Introduction}

Based on data from the National Cancer Registry, the incidence of skin cancer in the Polish population in 2010 was $6.8 \%$ in men and $7.5 \%$ in women [1]. The standardised rate for individuals aged 65 years or older was 146.4 and 96.8 in men and women, respectively. The number of registered skin cancers in 2010 was over 10,000. The exact skin cancer incidence in Poland is not known due to insufficient reporting to the National 
Cancer Registry. A good reference for the European population may be a Danish study, which revealed basal cell carcinoma (BCC) incidence in 2005 accounting for 6074 cases/100,000 among women aged 65 years or older and 6347 cases/100,000 among men, with a 5-6-fold increase in morbidity between 1973 and 2008. The authors of the study predict, based on current statistical data, that by 2020 the incidence in the group over 65 years old will be 16,282/100,000 and 20,019/100,000 in women in men, respectively [2].

Basal cell carcinoma is slow growing, slightly and locally aggressive tumour. The metastatic rate is estimated to be around $0.0028-0.55 \%$ [3]. It occurs most frequently in patients over 65 years of age (constituting over $95 \%$ of cases) and is located mainly in the facial area, $30 \%$ of which are within the nose, $7 \%$ around the orbit, and about $6 \%$ of lesions concern the ear. The occurrence of one $\mathrm{BCC}$ is associated with a $40 \%$ risk of occurrence a second one in the next five years; if there was more than one $\mathrm{BCC}$, the risk of the next lesion increases to $75 \%[2,3]$.

Vismodegib is a small-molecule drug belonging to the group of hedgehog pathway $(\mathrm{Hh})$ inhibitors, which has been registered by the US Food and Drug Administration (FDA) and European Medicines Agency (EMA), based on results of the ERIVANCE and STEVIE studies for the treatment of patients with symptomatic metastatic basal cell carcinoma (mBCC) or locally advanced basal cell carcinoma (laBCC), who are ineligible for surgery or radiotherapy [4-6]. Since $1^{\text {st }}$ January 2017, vismodegib has been accessible to patients in Poland as part of a drug program reimbursed by the National Health Fund (NFZ). The final qualification of patients for the program is carried out by the Coordination Team for the Treatment of Basal Cell Skin Cancer, appointed by the President of the NFZ. During the period from $1^{\text {st }}$ August 2017 to $30^{\text {th }}$ September 2018 a total of 78 patients started treatment with vismodegib in Poland.

\section{Aim of work}

The aim of the study was to analyse groups of patients qualified for vismodegib therapy, to assess the frequency of adverse events with determination of their severity according to Common Terminology Criteria for Adverse Events (CTCAE), and to summarise the outcomes after six and 12 months. Data regarding patients came from three centres: the Dermatology Clinic, Military Institute of Medicine, Central Clinical Hospital of the Ministry of National Defence in Warsaw, the Department of Melanoma and Soft Tissue and Bone Sarcomas, Maria Sklodowska-Curie Institute - Oncology Center in Warsaw, and the Department of Clinical and Experimental Oncology, Heliodor Swiecicki Clinical Hospital, Medical University in Poznan. These centres had a total of $42(53.8 \%)$ of the 78 patients treated with vismodegib throughout Poland.

\section{Patients and methods}

The analysis included 42 patients (30 male and $12 \mathrm{fe-}$ male) aged 33-87 years (mean 63.2). All patients were qualified to the program, according to inclusion criteria, due to the presence of histopathologically confirmed, locally advanced basal cell carcinoma; in seven out of 42 patients the additional criterion for inclusion was coexisting metastases (CNS 1/9, liver 1/9, lung 5/9, lymph nodes $1 / 9$, and bones $1 / 9)$. In addition, $5 / 42$ patients were diagnosed with Gorlin-Goltz syndrome (GGS). At qualification for participation in the program, all patients were disqualified from possible further surgical treatment and radiotherapy. Of the 42 patients, 27 had previously been treated surgically, 16 had had radiotherapy, and four had received chemotherapy; 2/42 patients had been unsuccessfully treated with three and 13/42 patients with two of the above methods. All patients met the remaining criteria for participation in the program, i.e. regarding laboratory tests, imaging evaluation, and performance status (PS) based on the Eastern Cooperative Oncology Group (ECOG), in accordance with the NFZ guidelines [7,8]. The drug in the form of capsules was taken orally in a single daily dose of $150 \mathrm{mg}$. Treatment was continued until the exclusion criteria were met: documented progression during the use of the drug, the occurrence of hypersensitivity symptoms to vismodegib or any of the excipients, the occurrence of an adverse event preventing further treatment, or patient withdrawal. The contraindication to vismodegib treatment included pregnancy and breastfeeding. Due to the teratogenicity of the drug it was necessary to use effective contraception during the therapy and after its completion (women for two years and men for two months). The duration of treatment in the 42 patients ranged between three weeks and 68 months. The analysis of the occurrence of individual adverse reactions and their severity according to CTCAE version 5.0 included 42 patients [9]. The patients were carefully monitored every $2-3$ months based on medical history, physical examination, laboratory tests, photographic documentation, and imaging examinations [8]. Response to treatment was assessed according to RECIST 1.1 after six and 12 months in 29/42 and $17 / 42$ patients, respectively [10]. The reason for treatment discontinuation and the time to progression in patients who did not respond to treatment were also shown. A summary of all data collected in the analysed population is presented in Table 1 . 
焉

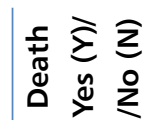

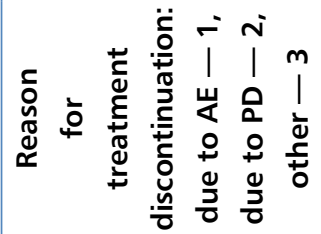

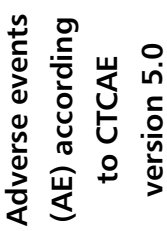

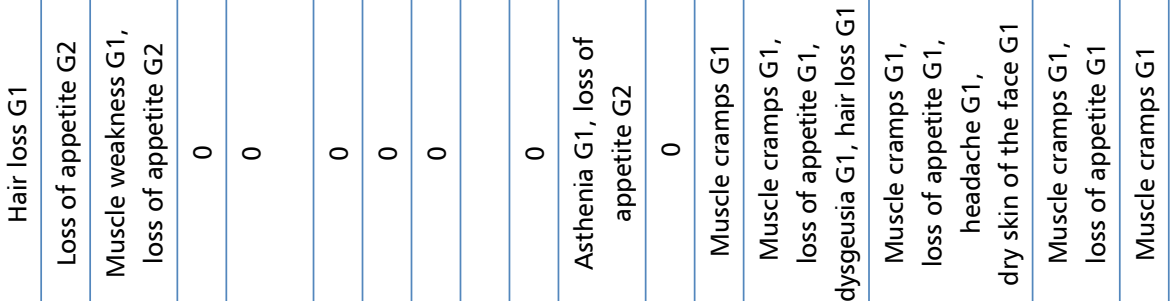

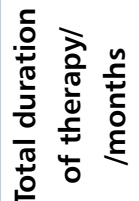

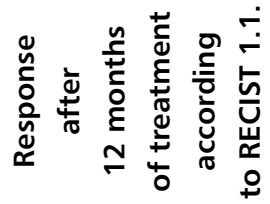

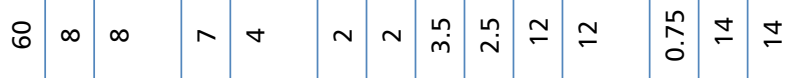

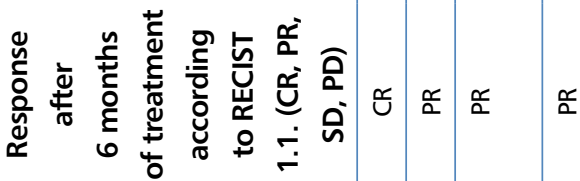

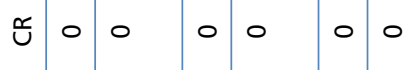

옹 i

in

$\stackrel{x}{2}$

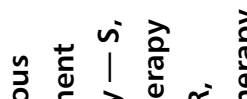

$\underline{\underline{O}}$

$\frac{\sqrt{2}}{\frac{0}{2}}$

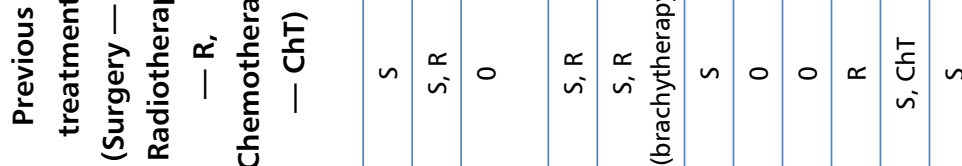

$\stackrel{x}{2}$ iิ

in

in

$\stackrel{\circ}{\circ}$

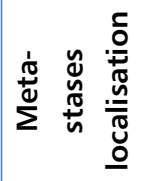

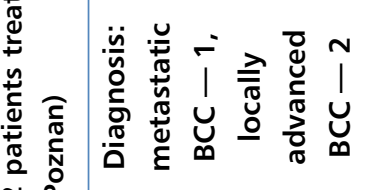

₹

这

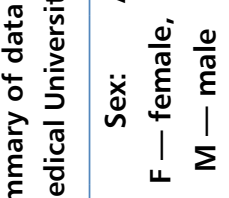

$\stackrel{n}{\circ}$

i

ธอง

$\infty \sim \infty$

$\bar{\varsigma}$

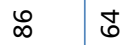

$\bar{s}$

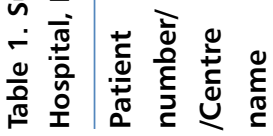

$\Sigma \Sigma \Sigma \Sigma \Sigma \Sigma \Sigma(\Sigma \sqcup \Sigma$ Ч ४ $\Sigma$

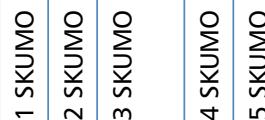

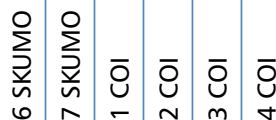

亏ิ

$\bar{\Xi}_{\infty}$

\begin{tabular}{l|l}
$\bar{\cup}$ & $\bar{U}$ \\
$\sigma$ & 0
\end{tabular} 


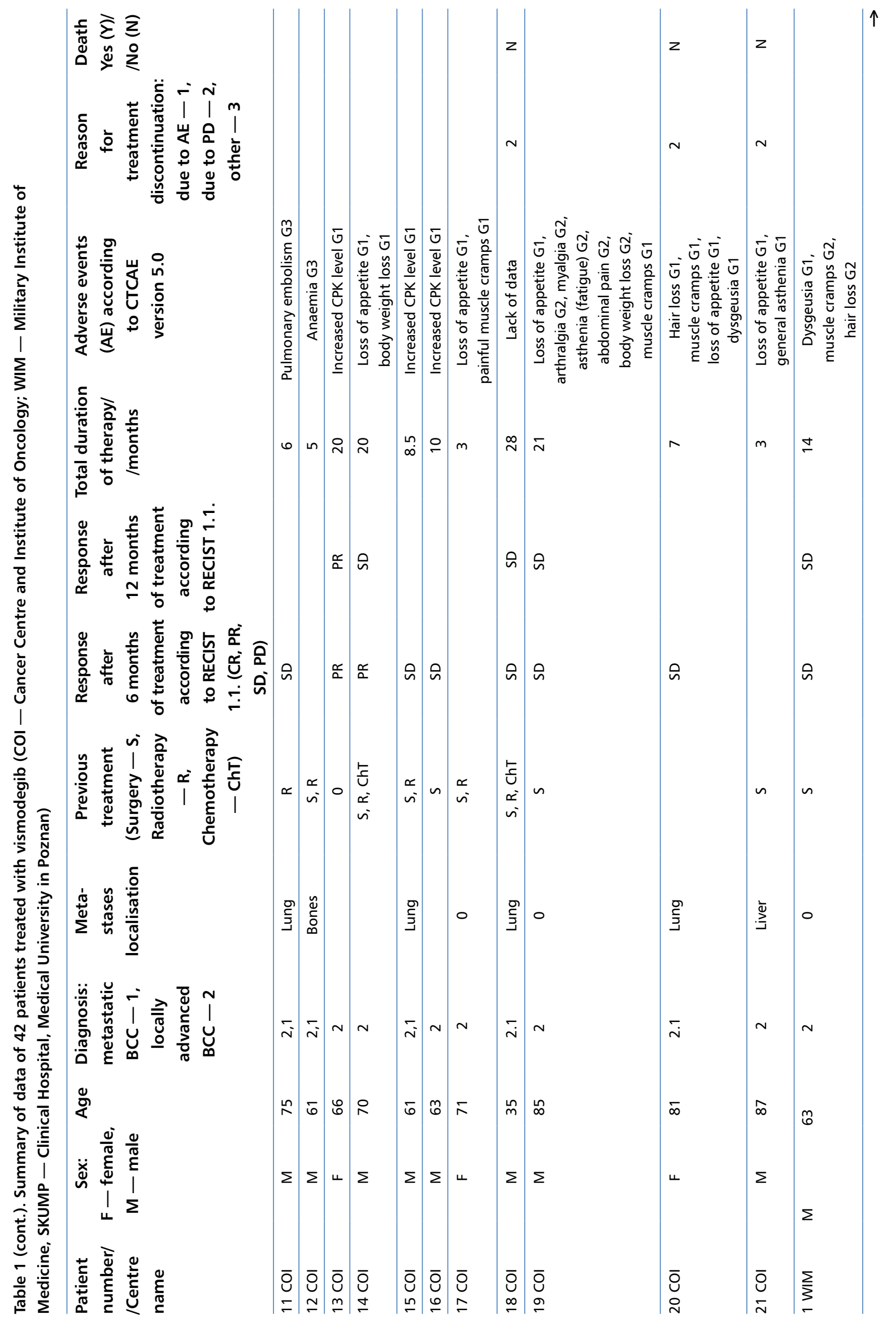




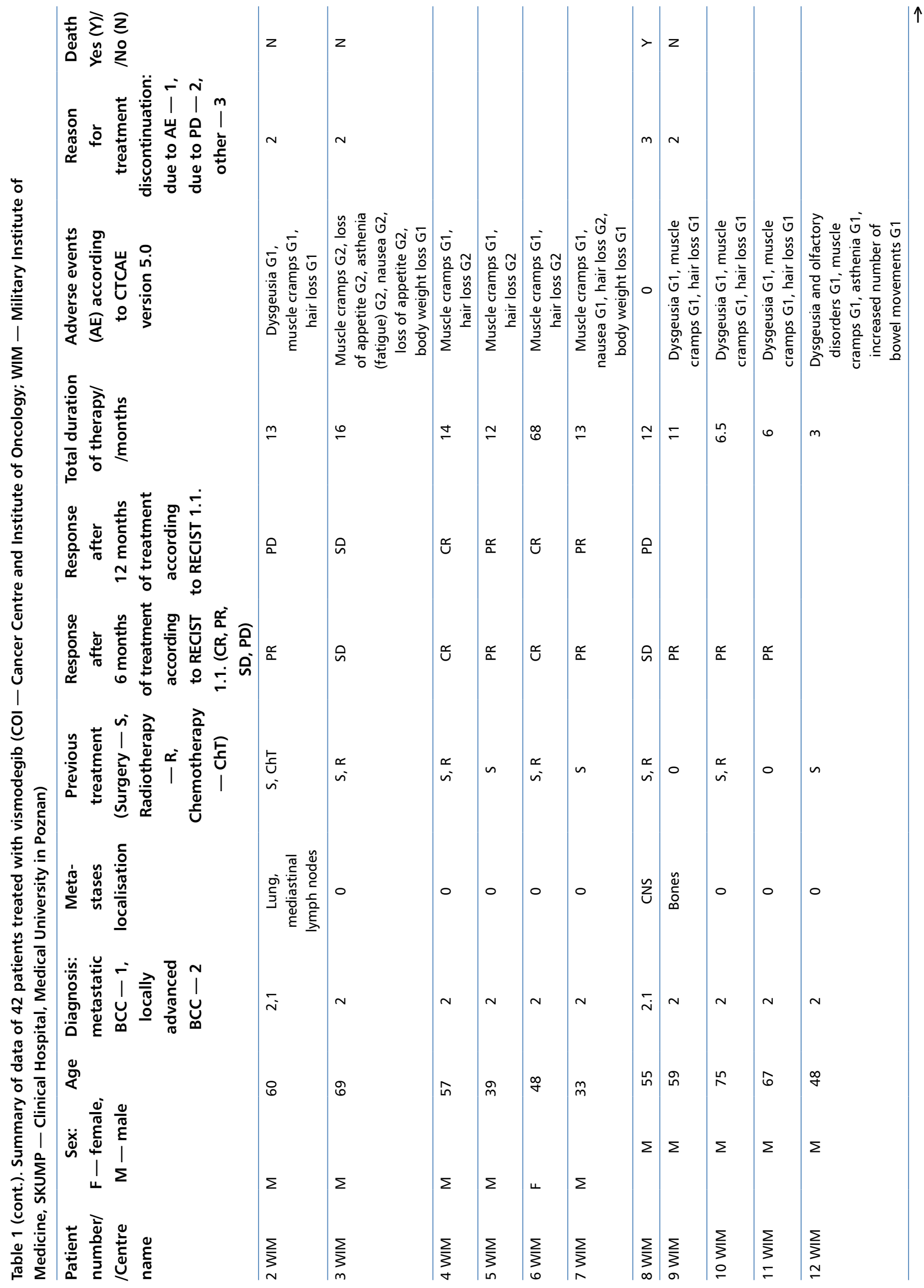




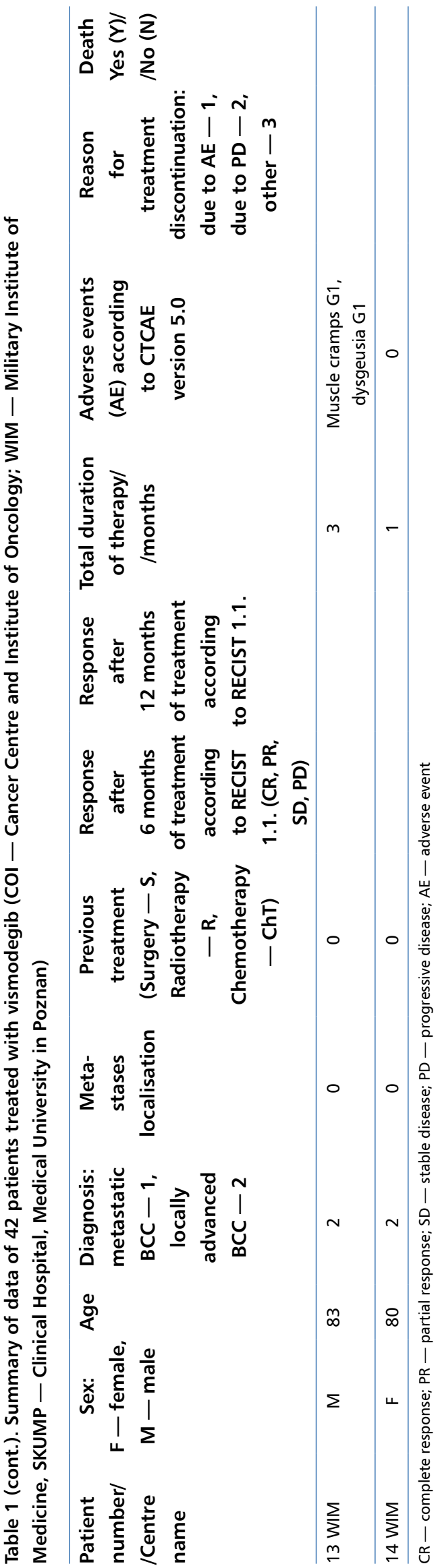

\section{Results}

The outcome summary of 42 patients is presented in Table 2 and 3 . At the time of writing, only 29 patients have completed 6 months of therapy, and 17 of them have completed 12 months. In the latter group there were three patients with metastases. The duration of treatment differed significantly and was between 0.75 and 68 months, with the median duration of treatment 8.25 months. Among patients who were treated for less than 12 months the median follow-up was 8 months, while in patients treated for more than 12 months the median follow-up was 14 months.

Table 4 presents the results of treatment effectiveness after 6 and 12 months in the study group in comparison with the results of the ERIVANCE and STEVIE studies as well as the EAS (expanded access study). However, the significant differences in the sizes of individual groups of patients, as well as the percentage of $\mathrm{mBCC}$ in the study group and the duration of treatment, should be highlighted $[4,5,11]$.

Table 5 presents a summary of occurrence of adverse reactions among 42 patients, as compared to the ERIVANCE, STEVIE, and EAS studies. It should be added that whilst 7 out of 42 patients discontinued treatment due to disease progression, there was no case of discontinuation of treatment due to adverse events, which occurred in a total of $73.8 \%$ of patients; however, $74.3 \%$ of AEs had G1 and $23 \%$ had G2 intensity according to CTCAE version 5.0. It should also be concluded that the frequency of reported adverse reactions both in total and in relation to individual signs/symptoms was significantly lower than demonstrated in the ERIVANCE, STEVIE, and EAS studies [4, 5, 11].

\section{Discussion}

The efficacy and safety of vismodegib treatment have been confirmed in the multicentre, non-randomised, international ERIVANCE study, the results of which were published in 2012 [4]. The study group included 104 patients with locally advanced (laBCC; 71/104, in total 63 patients were included in the final analysis) and metastatic basal cell carcinoma (mBCC; 33/104). The duration of treatment was 0.7-18.7 months, and the median was 10 months. The objective response rate (ORR) in the first group was $43 \%(95 \% \mathrm{CI}, 31-56, \mathrm{p}<0.001)$ and $30 \%$ in the second group (95\% CI; 16-48; $\mathrm{p}=0.001)$, while the response rate (RR) was $21 \%$. Disease stabilisation (SD) was obtained in $64 \%$ and $38 \%$ of patients, respectively, while progression of disease (PD) was found in 3\% and $13 \%$ of patients, respectively. Median duration of response (DOR) in both groups was 7.6 months, and the median 
Table 2. A summary of treatment responses according to the RECIST 1.1 criteria after 6 and 12 months of therapy

\begin{tabular}{|c|c|c|}
\hline $\begin{array}{l}\text { Treatment responses according to } \\
\text { the RECIST } 1.1 \text { criteria }\end{array}$ & After 6 months of therapy $(n=29)$ & After 12 months of therapy $(n=17)$ \\
\hline CR & $3(10.3 \%)$ & $3(17.6 \%)$ \\
\hline PR & $13(44.8 \%)$ & $5(29.4 \%)$ \\
\hline ORR $(C R+P R)$ & $16(55.1 \%)$ & $8(47 \%)$ \\
\hline SD & $13(44.8 \%)$ & $8(50.0 \%)$ \\
\hline PD & $\begin{array}{l}\text { Achieved by } 7 \text { out of } 42 \text { patients } \\
\begin{array}{l}\text { (16.6\%): } \\
-1 \text { after } 3 \text { months } \\
-0 \text { after } 6 \text { months } \\
-1 \text { after } 7 \text { months } \\
-1 \text { after } 11 \text { months } \\
-1 \text { after } 12 \text { months } \\
-1 \text { after } 13 \text { months } \\
-1 \text { after } 16 \text { months } \\
-1 \text { after } 28 \text { months }\end{array}\end{array}$ & \\
\hline
\end{tabular}

CR — complete response; PR — partial response; SD — stable disease; PD — progressive disease

Table 3. A summary of treatment responses according to the RECIST 1.1 criteria after 6 and 12 months of therapy in patients with metastatic cancer (7/42; of whom 3 patients were treated for less than 12 months, 1 patient was treated 3 months and therefore was not included in the summary)

\begin{tabular}{lcc}
\hline $\begin{array}{l}\text { Treatment responses according to } \\
\text { the RECIST 1.1 criteria }\end{array}$ & After $\mathbf{6}$ months of therapy $(n=6)$ & After $\mathbf{1 2}$ months of therapy $(n=3)$ \\
\hline CR & 0 & 0 \\
\hline PR & 1 & 0 \\
\hline SD & 5 & 1 \\
\hline PD & & 2
\end{tabular}

CR - complete response; PR — partial response; SD — stable disease; PD — progressive disease

progression-free survival (PFS) was 9.5 months. The results of this study led to the approval of vismodegib by the FDA and EMA for the treatment of advanced BCC patients.

In 2015 Lacouture et al. published the preliminary results of a prospective multicentre observational study planned for eight years to assess efficacy and safety in about 750 patients with advanced BCC stratified to three treatment groups: $\mathrm{C} 1$ - patients previously not treated with vismodegib, who will receive vismodegib, $\mathrm{C} 2$ - patients previously treated with vismodegib, who will undergo surgical treatment, and C3 - patients with Gorlin-Goltz syndrome with advanced BCC or numerous non-advanced BCC lesions, who may have been previously treated with sonic hedgehog pathway inhibitors [12]. The study started in June 2012 but was terminated by the sponsor in April 2017 due to the high percentage of patients who discontinued treatment (but not due to safety aspects). The authors summarised the treatment in the $\mathrm{C} 1$ group containing
77 patients and $\mathrm{C} 2$ containing 144 patients; ORR (95\% $\mathrm{CI}$ ) in $\mathrm{C} 1$ group was $68 \%$ (56-78), CR 45\% (35/77), PR $22 \%(17 / 77)$, while in the $\mathrm{C} 2$ group it was $61 \%, 60 \%$ $(86 / 144)$, and $1 \%(2 / 144)$, respectively. There were adverse reaction events in $82 \%(63 / 77)$ of patients in the $\mathrm{C} 1$ group and in $15 \%(22 / 144)$ in the $\mathrm{C} 2$ group, and serious adverse events in $14 \%(11 / 77)$ and $8 \%$ of patients (11/144), respectively. Interestingly, SCC (squamous cell carcinoma) was found only in the C2 group (64\% of patients; 7/11).

In 2014, based on results of the expanded access study (EAS), Chang et al. evaluated the effectiveness of treatment of 95 patients $(58.9 \%$ - laBCC, $41 \%$ - mBCC), after duration of treatment 5.5 months (0.4-19.6), including four patients previously treated with vismodegib [11]. In Table 4 it can be observed that the group of patients with laBCC in the EAS study achieved results similar to those presented by the Polish group after six months of treatment. This consistence can be interpreted in light of the small 
Table 4. A comparison of treatment effectiveness of locally advanced basal cell carcinoma (laBCC) and metastatic basal cell carcinoma $(\mathrm{mBCC})$ in the study group with the ERIVANCE, STEVIE, and EAS studies $[4,5,11]$

\begin{tabular}{|c|c|c|c|c|c|}
\hline $\begin{array}{l}\text { Treatment } \\
\text { responses } \\
\text { according to the } \\
\text { RECIST } 1.1 \\
\text { criteria }\end{array}$ & $\begin{array}{c}\text { After } \\
6 \text { months } \\
\text { of therapy } \\
(n=29 / 42)\end{array}$ & $\begin{array}{l}\text { After } 12 \text { months of } \\
\text { therapy } \\
(n=17 / 42)\end{array}$ & $\begin{array}{l}\text { The results of the } \\
\text { STEVIE study; median } \\
\text { treatment duration: } \\
9 \text { months (laBCC) } \\
\text { and } 13 \text { months (MBCC) } \\
\qquad(\mathrm{n}=482 / 499)\end{array}$ & $\begin{array}{l}\text { The results } \\
\text { of the expanded } \\
\text { access study (EAS); } \\
\text { median treatment } \\
\text { duration } 5.5 \text { months } \\
\qquad(n=95 / 119)\end{array}$ & $\begin{array}{c}\text { The results } \\
\text { of the ERIVANCE } \\
\text { study; median } \\
\text { treatment } \\
\text { duration } 10 \text { months } \\
\text { ( } n=96 / 104)\end{array}$ \\
\hline Patient groups & $\begin{array}{l}\text { laBCC } 79.3 \% \\
\text { mBCC } 20.6 \%\end{array}$ & $\begin{array}{l}\text { laBCC } 82.3 \% \\
\text { mBCC } 17.6 \%\end{array}$ & $\begin{array}{c}\text { laBCC } 93.9 \% \\
\text { mBCC } 6 \%\end{array}$ & $\begin{array}{l}\text { laBCC 58.9\%; } \\
\text { mBCC } 41.0 \%\end{array}$ & $\begin{array}{l}\text { laBCC 52\%; } \\
\text { mBCC } 31.7 \%\end{array}$ \\
\hline $\begin{array}{l}\text { Gorlin-Goltz } \\
\text { syndrome }\end{array}$ & $\begin{array}{c}17.2 \% \\
5-\mathrm{laBCC} \\
0-\mathrm{mBCC}\end{array}$ & $\begin{array}{c}23.5 \% \\
4-\mathrm{laBCC} \\
0-\mathrm{mBCC}\end{array}$ & $\begin{array}{c}20 \%(98 / 485) \\
96-\mathrm{laBCC} \\
2-\mathrm{mBCC}\end{array}$ & $\begin{array}{c}15.9 \%(19 / 119) \\
12-\mathrm{laBCC} \\
7-\mathrm{mBCC}\end{array}$ & $\begin{array}{c}31 \%(22 / 104) \\
22-\mathrm{laBCC} \\
0-\mathrm{mBCC}\end{array}$ \\
\hline CR & $\begin{array}{c}10.3 \% \\
3-\mathrm{laBCC} \\
0-\mathrm{mBCC}\end{array}$ & $\begin{array}{c}17.6 \% \\
3-\mathrm{laBCC} \\
0-\mathrm{mBCC}\end{array}$ & $\begin{array}{c}32 \% \\
34 \% \text { laBCC } \\
7 \% \mathrm{mBCC}\end{array}$ & $\begin{array}{c}10.7 \% \text { laBCC } \\
5.1 \% \mathrm{mBCC}\end{array}$ & $\begin{array}{c}31.7 \% \text { laBCC } \\
\text { O\% mBCC }\end{array}$ \\
\hline PR & $\begin{array}{c}44.8 \% \\
12-\mathrm{laBCC} \\
1-\mathrm{mBCC}\end{array}$ & $\begin{array}{c}29.4 \% \\
5-\mathrm{laBCC} \\
0-\mathrm{mBCC}\end{array}$ & $\begin{array}{c}33 \% \\
33 \% \mathrm{laBCC} \\
31 \% \mathrm{mBCC} \\
\end{array}$ & $\begin{array}{l}35.7 \% \mathrm{laBCC} \\
25.6 \% \mathrm{mBCC}\end{array}$ & $\begin{array}{l}28.5 \% \mathrm{laBCC} \\
45.4 \% \mathrm{mBCC}\end{array}$ \\
\hline $\begin{array}{l}\text { ORR /OR } \\
(\mathrm{CR}+\mathrm{PR})\end{array}$ & $\begin{array}{c}55.1 \% \\
15-\mathrm{laBCC} \\
1-\mathrm{mBCC}\end{array}$ & $\begin{array}{c}47 \% \\
8-\mathrm{laBCC} \\
0-\mathrm{mBCC}\end{array}$ & $\begin{array}{l}66.7 \% \mathrm{laBCC} \\
37.9 \% \mathrm{mBCC}\end{array}$ & $\begin{array}{l}46.4 \% \mathrm{laBCC} \\
30.8 \% \mathrm{mBCC}\end{array}$ & $\begin{array}{l}60.3 \% \mathrm{laBCC} \\
45.5 \% \mathrm{mBCC}\end{array}$ \\
\hline SD & $\begin{array}{c}44.8 \% \\
8-\mathrm{laBCC} \\
5-\mathrm{mBCC}\end{array}$ & $\begin{array}{c}50.0 \% \\
7-\mathrm{laBCC} \\
1-\mathrm{mBCC}\end{array}$ & $\begin{array}{c}27 \% \\
26 \% \text { laBCC } \\
34 \% \mathrm{mBCC}\end{array}$ & $\begin{array}{l}48.2 \% \mathrm{laBCC} \\
51.3 \% \mathrm{mBCC}\end{array}$ & $\begin{array}{l}38 \% \text { laBCC } \\
64 \% \mathrm{mBCC}\end{array}$ \\
\hline PD & $\begin{array}{c}3.4 \% \\
0-\text { laBCC } \\
1-\mathrm{mBCC} \\
\text { (after } \\
3 \text { months) }\end{array}$ & $\begin{array}{c}17.6 \% \\
0-\mathrm{laBCC} \\
3-\mathrm{mBCC}\end{array}$ & $\begin{array}{c}3 \% \\
2 \% \text { laBCC } \\
14 \% \text { mBCC }\end{array}$ & $\begin{array}{c}0 \% \mathrm{laBCC} \\
7.7 \% \mathrm{mBCC}\end{array}$ & $\begin{array}{c}9.5 \% \text { laBCC } \\
6 \% \mathrm{mBCC}\end{array}$ \\
\hline
\end{tabular}

CR — complete response; PR — partial response; SD — stable disease; PD — progressive disease; laBCC — locally advanced basal cell carcinoma; mBCC - metastatic basal cell carcinoma

number of patients who were treated for 12 months, so the majority of data from authors of this article relate to a group with a duration of treatment similar to the EAS.

The STEVIE study, the first results of which were published in 2015, involved 1277 patients treated with vismodegib, of whom 499 (468 with laBCC and 31 with $\mathrm{mBCC}$ ) were evaluated in safety set and 482 (453 with laBCC and 29 with $\mathrm{mBCC}$ ) in an efficacy set [5]. The median duration of treatment was 36.3 weeks (17.6-60.0) for laBCC and 52 weeks (23.3-76.0) for $\mathrm{mBCC}$ patients. Based on the investigators assessment, overall response (OR) was found in $302(66.7 \%$, 62.1-71.0) of 453 laBCC patients, including 153 complete responses (CR) and 149 partial responses (PR). In total $11(37.9 \%, 20.7-57.7)$ out of $29 \mathrm{mBCC}$ patients responded to the treatment (OR), with two (7\%) and nine $(31 \%)$ patients receiving complete and partial response, respectively. In total $400(80 \%)$ patients discontinued the study: $36 \%$ due to adverse reactions, $14 \%$ due to disease progression, and $10 \%$ based on the patient's decision. The safety profile was comparable to that in the ERIVANCE study. Of note, there were far fewer adverse reactions reported among patients in the Polish group compared to $98-100 \%$ of patients from the studies cited above (Table 5), and none of the patients discontinued the treatment due to AEs occurrence. Based on the data from the STEVIE and ERIVANCE studies, it is known that the average time to onset of adverse reactions varies depending on its nature (2.8 months for muscle cramps, 5.5 months for alopecia, and 6.5 months for dysgeusia) and account for two months on average $[4,5]$. Hence, the short duration of treatment and the small number of Polish patients could be an explanation for these discrepancies. The concentration of these patients in three centres with extensive experience in the treatment of skin cancers is important for the reported results of the group of patients examined by the authors of this article.

In 2016 Chang et al. evaluated the effectiveness of treatment of patients with Gorlin-Goltz syndrome, qualified as laBCC or $\mathrm{mBCC}$ in the ERIVANCE and 
Table 5. A collation of adverse events (AE) incidence in the study group in comparison to the ERIVANCE, STEVIE, and EAS studies [4, 5, 11]

\begin{tabular}{|c|c|c|c|c|c|}
\hline & $\begin{array}{c}\text { Total number } \\
\text { of AEs }\end{array}$ & $\begin{array}{l}\text { Intensity grade } \\
\text { according to } \\
\text { CTCAE, } \\
\text { version } 5.0\end{array}$ & $\begin{array}{c}\text { AE incidence } \\
\text { in the ERIVANCE } \\
\text { study }\end{array}$ & $\begin{array}{c}\text { AE incidence } \\
\text { in the STEVIE } \\
\text { study }\end{array}$ & $\begin{array}{c}\text { AE incidence } \\
\text { in EAS } \\
\text { study }\end{array}$ \\
\hline Total AE & $\begin{array}{c}\mathrm{AE}-73.8 \% \\
(31 / 42) \\
>1 \mathrm{AE} / \text { patient } \\
52.3 \%(22 / 42)\end{array}$ & $\begin{array}{c}\mathrm{G} 1-74.3 \% \\
(58 / 78) \\
\mathrm{G} 2-23.0 \% \\
(18 / 78) \\
\mathrm{G} 3-2.5 \%(2 / 78)\end{array}$ & $\begin{array}{c}100 \%(104 / 104) \\
>1-2 \mathrm{AE} / \\
\text { /patient } 57 \%\end{array}$ & 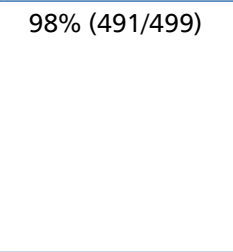 & $\begin{array}{c}97.5 \%(116 / 119) \\
\text { G1-2 }=67.2 \% \\
(80 / 119) \\
\text { G3 }=20.1 \% \\
(24 / 119) \\
\text { G4 }=7.5 \%(9 / 119) \\
\text { G5 }=2.5 \%(3 / 119)^{*}\end{array}$ \\
\hline Muscle cramps & $47.6 \%(20 / 42)$ & $\begin{array}{l}\mathrm{G} 1-18 \\
\mathrm{G} 2-2\end{array}$ & $68 \%$ & $64 \%$ & $70.6 \%$ \\
\hline Hair loss & $28.5 \%(12 / 42)$ & $\begin{array}{l}\mathrm{G} 1-7 \\
\mathrm{G} 2-5\end{array}$ & $63 \%$ & $62 \%$ & $58 \%$ \\
\hline Loss of appetite & $28.5 \%(12 / 42)$ & $\begin{array}{l}\mathrm{G} 1-8 \\
\mathrm{G} 2-4\end{array}$ & $23 \%$ & $25 \%$ & \\
\hline Dysgeusia & $23.8 \%(10 / 42)$ & $\begin{array}{l}\mathrm{G} 1-9 \\
\mathrm{G} 2-1\end{array}$ & $51 \%$ & $54 \%$ & $70.6 \%$ \\
\hline Asthenia/fatigue & $11.9 \%(5 / 42)$ & $\begin{array}{l}\mathrm{G} 1-3 \\
\mathrm{G} 2-2\end{array}$ & $36 \%$ & $28 \% / 16 \%$ & $19.3 \%$ \\
\hline Body weight loss & $9.5 \%(4 / 42)$ & $\begin{array}{l}\mathrm{G} 1-3 \\
\mathrm{G} 2-1\end{array}$ & $46 \%$ & $33 \%$ & $16 \%$ \\
\hline Increased creatine kinase level & $7.1 \%(3 / 42)$ & $\mathrm{G} 1-3$ & 0 & 0 & \\
\hline Nausea & $4.7 \%(2 / 42)$ & $\begin{array}{l}\mathrm{G} 1-1 \\
\mathrm{G} 2-1\end{array}$ & $29 \%$ & $16 \%$ & $19.3 \%$ \\
\hline Abdominal pain & $2.3 \%(1 / 42)$ & $\mathrm{G} 2-1$ & & & \\
\hline Headache & $2.3 \%(1 / 42)$ & $\mathrm{G} 1-1$ & & & \\
\hline Olfactory disorders & $2.3 \%(1 / 42)$ & $\mathrm{G} 1-1$ & & & \\
\hline Anaemia & $2.3 \%(1 / 42)$ & $\mathrm{G} 3-1$ & & & \\
\hline Pulmonary embolism & $2.3 \%(1 / 42)$ & $\mathrm{G} 3-1$ & & & \\
\hline Myalgia & $2.3 \%(1 / 42)$ & $\mathrm{G} 1-1$ & & & \\
\hline $\begin{array}{l}\text { Increased number of bowel } \\
\text { movements }\end{array}$ & $2.3 \%(1 / 42)$ & $\mathrm{G} 1-1$ & Diarrhoea $22 \%$ & Diarrhoea 17\% & Diarrhoea $25.2 \%$ \\
\hline Dry skin & $2.3 \%(1 / 42)$ & $\mathrm{G} 1-1$ & & & \\
\hline Arthralgia & $2.3 \%(1 / 42)$ & $\mathrm{G} 2-1$ & & & \\
\hline Muscle weakness & $2.3 \%(1 / 42)$ & $\mathrm{G} 1-1$ & & & \\
\hline $\begin{array}{l}\text { Death due to progression } \\
\text { disease }\end{array}$ & $2.3 \%(1 / 42)$ & & & $\begin{array}{c}6 \% \\
31 / 499 \text { patients } \\
\text { died due to: } \\
\text { - progression of } \\
\text { disease } 5 / 499 \\
\text { - AE } 21 / 499 \\
\text { - others } 5 / 499\end{array}$ & $\begin{array}{c}2.5 \% \text { died } \\
2 \text { with mBCC due } \\
\text { to progression } \\
\text { of disease; } \\
1 \text { with laBCC due to } \\
\text { SCC dissemination }\end{array}$ \\
\hline SAE & & & $25 \%$ & $\begin{array}{c}22 \%(108 / 499) \\
\text { deterioration of } \\
\text { general health, } \\
\text { dehydration, SCC, } \\
\text { pneumonia }\end{array}$ & $\begin{array}{l}\text { SAE G3-G5 15.1\% } \\
\text { (18/119): } \\
\text { mesothelioma, } \\
\text { recurrence of } \\
\text { B-cell lymphoma, } \\
\text { recurrence/ } \\
\text { /dissemination } \\
\text { of SCC, muscle } \\
\text { cramps }\end{array}$ \\
\hline
\end{tabular}

SAE — serious adverse event; AE — adverse event; CTCAE — Common Terminology Criteria for Adverse Events; SCC — squamous cell carcinoma; laBCC — locally advanced basal cell carcinoma; $\mathrm{mBCC}$ - metastatic basal cell carcinoma 
EAS studies [13]. In the ERIVANCE study all patients diagnosed with GGS were in the laBCC group (21/63), while in the EAS study 12/56 study in the laBCC group and $6 / 39$ in the mBCC group. Although the authors did not find a statistically significant difference in treatment efficacy between GGS and non-GGS patients, there is a tendency towards a lower percentage of SD and PD in the GGS group. In the ERIVANCE study ORR (CR and PR) in patients with GGS was $81 \%$ (CR $-38 \%, \mathrm{OR}-43 \%), \mathrm{SD}-14 \%$, and $\mathrm{PD}-5 \%$, whereas in the group without GGS, $50 \%$ (CR - 29\%, PR $-21 \%$ ), $29 \%$, and $12 \%$, respectively. In turn, in the EAS study the above differences disappear: in the laBCC group with GGS the ORR was $33 \%$ (CR - 8\%, $\mathrm{PR}-25 \%), \mathrm{SD}-50 \%$, and $\mathrm{PD}-17 \%$, while without GGS the ORR was $50 \%$ (CR - 11\%, PR - 39\%), $\mathrm{SD}-48 \%$, and $\mathrm{PD}-0 \%$. In the group of patients with $\mathrm{mBCC}$ and GGS the ORR was 50 (CR - 33\%, $\mathrm{PR}-17 \%), \mathrm{SD}-50 \%$, and $\mathrm{PD}-0 \%$, while in the group without GSS the ORR was $27 \%$ (CR - $0 \%$, $\mathrm{PR}-27 \%), \mathrm{SD}-52 \%$, and PD - 9\%. In the Polish group 5/42 patients were diagnosed with GGS. Among patients treated for six months, they constituted $17.2 \%$ (5), of whom four $(23.5 \%)$ were treated for 12 months. All patients achieved a response (CR or PR).

In a publication from 2017 summarising the OS after a period of approximately 39.1 months of follow-up of 104 patients from the ERIVANCE study, Sekulic et al. reported 30 deaths $(51.5 \%, 17 / 33$ in mBCC patients and 20.6\%, 13/63 in laBCC patients); the median OS for mBCC was 33.4 months, whereas for laBCC it was not achieved because it exceeded the survival rate for this group of patients [14]. The median follow-up for OS assessment in both groups was 39.1 months, and the estimated survival according to Kaplan-Meier after the first year was $78.7 \%$ in the $\mathrm{mBCC}$ group (95\% CI, 64.7-92.7) and 93.2\% (95\% CI, 86.8-99.6) in the laBCC group. The two-year survival rates of these patients were $62.3 \%$ (95\% CI, 45.4-79.3) in the mBCC group and $85.5 \%$ (95\% CI, 76.1-94.8) in the laBCC group. The observations of the authors of this article do not allow for the assessment of data after such a long period of observation. The problem that should be taken into account in the treatment of patients with advanced BCC is the emerging of resistance to vismodegib, resulting from the mutation of the Hh pathway proteins and the genes that they regulate, as well as from the transformation/coexistence of the squamous cell carcinoma component within BCC [15]. The situation is hampered by the fact that in Poland there are no other therapeutic options available for these patients. The authors of this article await the upcoming results of efficacy and safety of vismodegib in combination with radiotherapy or surgical treatment in adjuvant and neoadjuvant therapy $[16,17]$.

\section{Conclusions}

Currently, vismodegib is the only therapeutic option available in Poland for patients with locally advanced or metastatic basal cell carcinoma, who cannot be treated with surgery or radiotherapy [18]. Despite common side effects, the majority of them had G1 or G2 intensity according to CTCAE, and the results presented confirm the efficacy of vismodegib in routine oncological practice as part of the NFZ drug program.

\section{References}

1. Krajowy Rejestr Nowotworów - http://onkologia. org pl/nowotwory-skory-c44.

2. Flohil SC, de Vries E, Neumann HA, et al. Incidence, prevalence and future trends of primary basal cell carcinoma in the Netherlands. Acta Derm Venereol. 2011; 91(1): 24-30, doi: 10.2340/00015555-1009, indexed in Pubmed: 21264452.

3. Bichakjian CK, Alam M, Kim JYS, et al. Work Group, Invited Reviewers. Guidelines of care for the management of basal cell carcinoma. J Am Acad Dermatol. 2018; 78(3): 540-559, doi: 10.1016/j. jaad.2017.10.006, indexed in Pubmed: 29331385.

4. Sekulic A, Migden MR, Oro AE, et al. Efficacy and Safety of Vismodegib in Advanced Basal-Cell Carcinoma, N Engl J Med. 2012; 366: 2171-2179.

5. Basset-Seguin N, Hauschild A, Grob JJ, et al. Vismodegib in patients with advanced basal cell carcinoma (STEVIE): a pre-planned interim analysis of an international, open-label trial. The Lancet Oncology. 2015; 16(6): 729-736, doi: 10.1016/s1470-2045(15)70198-1.

6. Wismodegib - Charakterystyka produktu leczniczego. https://www. roche. pl/content/dam/roche poland $\mathrm{rwd} / \mathrm{pl} \mathrm{PL} /$ documents/SmPC/erivedge.pdf.

7. Eastern Cooperative Oncology Group (ECOG) http://www.npcrc. org/files/news/ECOG performance status.pdf.

8. Załącznik B.88. do programu leczenia zaawansowanego raka podstawnokomórkowego wismodegibem. http://onkologia-online pl/upload/obwieszczenie/2016 12 28/b/b. ; 88: pdf.

9. Common Terminology Criteria for Adverse Events (CTCAE) Version 5.0 Published: November 27, 2017 U.S. Department Of Health And Human Services https://ctep.cancer.gov/protocoldevelopment/electronic applications/docs/CTCAE v5 Quick Reference 5x7.pdf.

10. Płużański A. Kryteria oceny odpowiedżi na leczenie RECIST 1.1. Nowotwory. Journal of Oncology. 2014; 64(4): 331-335, doi: 10.5603/njo.2014.0055.

11. Chang AL, Solomon JA, Hainsworth JD, et al. Expanded access study of patients with advanced basal cell carcinoma treated with the Hedgehog pathway inhibitor, vismodegib. J Am Acad Dermatol. 2014; 70(1): 60-69, doi: 10.1016/j.jaad.2013.09.012, indexed in Pubmed: 24189279

12. Lacouture M, Guillen J, Kudchadkar R, et al. The RegiSONIC Disease Registry Study: Safety and effectiveness of vismodegib or surgery as primary treatment in patients with locally advanced basal cell carcinoma. European Journal of Cancer. 2015; 51: S679-S680, doi: 10.1016/s0959-8049(16)31859-7.

13. Chang AL, Arron ST, Migden MR, et al. Safety and efficacy of vismodegib in patients with basal cell carcinoma nevus syndrome: pooled analysis of two trials. Orphanet J Rare Dis. 2016; 11(1): 120, doi: 10.1186/s13023-016-0506-Z, indexed in Pubmed: 27581207

14. Sekulic A, Migden MR, Basset-Seguin N, et al. ERIVANCE BCC Investigators. Long-term safety and efficacy of vismodegib in patients with advanced basal cell carcinoma: final update of the pivotal ERIVANCE BCC study. BMC Cancer. 2017; 17(1): 332, doi: 10.1186/s12885-0173286-5, indexed in Pubmed: 28511673.

15. Zhao J, Quan H, Xie C, et al. NL-103, a novel dual-targeted inhibitor of histone deacetylases and hedgehog pathway, effectively overco- 
mes vismodegib resistance conferred by Smo mutations. Pharmaco Res Perspect. 2014; 2(3): e00043, doi: 10.1002/prp2.43, indexed in Pubmed: 25505589.

16. Kwon GP, Ally MS, Bailey-Healy I, et al. Update to an open-label clinica trial of vismodegib as neoadjuvant before surgery for high-risk basal cell carcinoma (BCC). J Am Acad Dermatol. 2016; 75(1): 213-215, doi: 10.1016/j.jaad.2016.02.1235, indexed in Pubmed: 27317518
17. Gathings RM, Orscheln CS, Huang WW. Compassionate use of vismodegib and adjuvant radiotherapy in the treatment of multiple locally advanced and inoperable basal cell carcinomas and squamous cell carcinomas of the skin. J Am Acad Dermatol. 2014; 70(4): e88-e89, doi: 10.1016/j.jaad.2013.11.032, indexed in Pubmed: 24629372.

18. Rutkowski P, Owczarek W. (eds). Skin carcinomas. Oncol Clin Pract. 2018; 14(3): 129-147. 